\title{
NANOMECHANICAL CHARACTERIZATION OF APOLIPOPROTEIN A-I AMYLOID FIBRILS
}

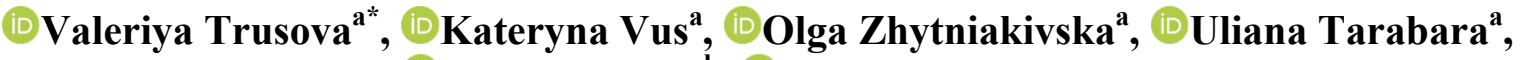 \\ (D)Hiroyuki Saito ${ }^{b}$, Galyna Gorbenko ${ }^{a}$ \\ ${ }^{a}$ Department of Medical Physics and Biomedical Nanotechnologies, V.N. Karazin Kharkiv National University \\ 4 Svobody Sq., Kharkiv, 61022, Ukraine \\ ${ }^{b}$ Department of Biophysical Chemistry, Kyoto Pharmaceutical University \\ 5 Misasagi-Nakauchi-cho, Yamashina-ku, Kyoto, 607-8414, Japan \\ *Corresponding Author: valerija.trusova@karazin.ua \\ Received March 26, 2020, revised March 29, 2020; accepted March 30, 2020
}

\begin{abstract}
Amyloid fibrils represent a special type of protein aggregates that are currently receiving enormous attention due to their strong implication in molecular etiology of a wide range of human disorders. Amyloid fibrils represent highly ordered self-assemblies sharing a core cross- $\beta$-sheet structure. Such organization of the fibrils is responsible for amyloid insolubility and exceptional mechanical properties. The remarkable rigidity of the protein fibrillar aggregates is due to intra- and interstrand hydrogen bonds which stabilize the $\beta$-strand scaffold of amyloid fibrils. Increasing evidence indicates that physical properties of amyloid assemblies, especially their mechanical characteristics, play essential role in determining their cytotoxic action. This highlights the necessity of deciphering the correlation between the elastic properties of amyloid aggregates and their cytotoxicity. In the present paper we utilized the atomic force microscopy (AFM) to visualize and analyze the amyloid fibrils of G26R/W@8 mutant of N-terminal fragment of human apolipoprotein A-I (apoA-I). The examination of AFM images revealed the existence of two polymorphic forms of apoA-I fibrils - twisted ribbon and helical ribbon. The quantitative analysis of apoA-I elastic properties was performed within the framework of worm-like model of polymer chain using the Easyworm software. The Easyworm package analyzes the images of individual polymer chains obtained by the atomic force microscopy and allows calculation of the persistent length of a chain in three regimes depending on the ratio between the contour and persistent lengths of the polymer. The set of evaluated parameters included the Young's modulus, persistent length, bending rigidity and the second moment of inertia. All parameters calculated for the helical ribbon conformation were higher than those of the twisted ribbon. These findings suggest that helical ribbon represents a more rigid and mechanically stable configuration. The results obtained may prove of importance for a deeper understanding the mechanicsdriven pathological activities of amyloid fibrils.
\end{abstract}

KEYWORDS: amyloid fibrils, mechanical properties, worm-like model, atomic force microscopy, Easyworm

A fundamental propensity of polypeptide chain for self-assembly has a dual nature reflected in protein folding into a functionally active native state and misfolding that provokes protein oligomerization and aggregation [1,2]. All these processes are driven by the common forces and crucially depend on the environmental conditions. The intermolecular noncovalent interactions may stabilize a diversity of supramolecular assemblies whose structures range from disordered amorphous aggregates to the crystals with strictly defined three-dimensional symmetry. Along with a naturally occurring protein self-association, there exists a so-called pathological aggregation leading to the formation of amyloid fibrils. During the past decades amyloid protein aggregates remain a focus of extensive research activities due to their involvement in the development of numerous human disorders, including neurodegenerative diseases, type II diabetes, spongiform encephalopathies, etc [3]. Increasing evidence from both theoretical and experimental in vitro and in vivo studies suggests that amyloid proteins and peptides can self-associate into fibrillar structures of different morphologies [4]. This gives rise to variability in amyloid fibril conformations and distinctions in their toxic potential and pathology-spreading properties. Accordingly, it was shown that various fibril polymorphs are characterized by different ability to act as a catalytic surface for secondary nucleation [5], as well as by distinct biological activities, such as propagation in a prion-like manner or association with cytotoxic active species [6]. Furthermore, a polymorphic behavior is believed to be a fundamental characteristic of a protein fibrillar state. The existence of different polymorphs was reported for A $\beta$-peptide, prion proteins, $\alpha$-synuclein, albumin, insulin, $\beta$-lactoglobulin, just to name a few. One of the most popular type of polymorphism is called lateral, or morphological one, and involves the transition from socalled twisted ribbon (TR) conformation to nanotube-like (NT) structure through the intermediate state called helical ribbon (HR) [7]. The driving force for the polymorphism is thought to be the variations in the number of protofilaments composing the fibril, that results in different twist and curvature of the final protein fibrillar assembly [8].

In general, characterization of the protein polymorphs is performed in a qualitative manner using the different microscopic techniques [9-11]. However, due to well-established key role of structural polymorphism in determining the amyloid cytotoxic activity, evaluation of the quantitative parameters of different amyloid conformations seems to be of great importance. In view of this, the aim of the present study was the examination of the polymorphic behavior of G26R/W@8 mutant of human apolipoprotein A-I (apoA-I) and analysis of its mechanical properties. The atomic force microscopy (AFM) was used in order to visualize, identify, classify and quantify in detail the distinct polymorphic species of apoA-I. 


\section{EXPERIMENTAL SECTION}

\section{Materials}

G26R/W@8 mutant of N-terminal fragment (1-83) of human apoA-I was obtained as described previously [12]. To prepare the amyloid fibrils, apoA-I variant was freshly dialyzed from $6 \mathrm{M}$ guanidine hydrochloride solution into 10 $\mathrm{mM}$ Tris buffer, $150 \mathrm{mM} \mathrm{NaCl}, 0.01 \% \mathrm{NaN}_{3}, \mathrm{pH} 7.4$ before use. The reaction of protein fibrillization was conducted at $37{ }^{\circ} \mathrm{C}$ in the above buffer with constant agitation on an orbital shaker. The amyloid nature of fibrillar aggregates was confirmed in Thioflavin T (ThT) assay [13]. All other reagents were used without further purification.

\section{Atomic force microscopy}

AFM imaging was carried out with a NanoScope IIIa scanning probe work station equipped with a MultiMode head using an E-series piezoceramic scanner (Digital Instruments, Santa Barbara, CA, USA). AFM probes were singlecrystal silicon microcantilevers with $300 \mathrm{kHz}$ resonant frequencies and $26 \mathrm{~N} / \mathrm{m}$ spring constant model OMCLAC160TS-R3 (Olympus, Tokyo, Japan). $10 \mu \mathrm{l}$ of each sample solution was spotted on freshly cleaved mica (The Nilaco Co., Tokyo, Japan). After washing the mica with distilled water $(20 \mu \mathrm{l})$, samples were imaged under ambient conditions at room temperature at scan rates of $0.5 \mathrm{~Hz}$ by tapping mode.

\section{RESULTS AND DISCUSSION}

Among a wide variety of different filamentous morphologies which can be adopted by protein aggregates, the configurations such as twisted ribbon, helical ribbon and nanotubes (NT) are among the most frequently appeared. TR conformation is characterized by a saddle-like curvature, straight central axis and a constant pitch. In turn, HR and NT represent the polymorphs with a high mean curvature but zero Gaussian curvature, helical centerline and a constant tilt angle. The transition from a twisted ribbon to a helical ribbon occurs at increasing number of protofilaments, and the accompanying rise in the width-to-thickness ratio, resulting from the protein tendency to minimize the bending and torsional energy. A further transformation of HR into a nanotube is associated with extra energy due to the edge line tension. The surface curvatures of the twisted $\left(\kappa_{T R}\right)$ and helical $\left(\kappa_{H R}\right)$ ribbons are given by:

$$
\kappa_{T R}=\frac{0.5 w-d_{T R}}{\left(0.5 w-d_{T R}\right)^{2}+\left(P_{T R} / 2 \pi\right)^{2}} ; \quad \kappa_{H R}=\frac{r_{h}}{r_{h}^{2}+\left(P_{H R} / 2 \pi\right)^{2}} ; \quad P_{H R}=2 \pi r_{h} \tan \psi
$$

where $w$ is the width of fibril core, $d_{T R}$ stands for the distance from the ribbon edge; $P_{T R}, P_{H R}$ denote fibril pitch either in TR or in HR conformation, respectively; $r_{h}$ is the helix radius; $\psi$ is the pitch angle. In our previous study [13] we derived the structural parameters of the twisted and helical ribbon polymorphs of G26R/W@8 fibrils from the AFM data, that were found to be: $w=10 \mathrm{~nm}, P_{T R}=50 \mathrm{~nm}$ for the twisted ribbon, and $r_{h}=5 \mathrm{~nm}, \psi=70^{\circ}$ for the helical ribbon.

Fig. 1 represents the AFM image of fibrillar G26R/W@8 mutant of apoA-I. As seen from this figure, the amyloid fibrils are visualized as smoothed or twisted structures. This observation suggests the existence of at least two different polymorphic forms of fibrillar polypeptide. The analysis of height profiles along the contour length showed that these polymorphs correspond to TR and HR configurations.

From the physical viewpoint amyloid fibrils are considered as supramolecular semi-elastic polymers which are not subject to Gaussian statistics. The reason of non-Gaussian nature of amyloid fibrils lies in their increased rigidity which results in the lack of the number of independent segments for application of the Gaussian statistics. An increased rigidity of polymeric chains may originate from several factors, among which are: i) sterical restrictions arising from the repulsion of atoms which are getting closer upon segment rotation; ii) electrostatic interactions; iii) H-bond formation. The description of rigid polymer molecules is generally based on the worm-like model which represents the continuous version of the Kratky-Porod model [14]. Within the framework of this approach, the following conditions are valid for a persistent chain: i) the segment length $l \rightarrow 0$, ii) the angle between the segments $\alpha \rightarrow \pi$, so the chain is characterized by a continuous curvature equal to the mean value of the cosine of the angle $\psi$ between the tangents to the chain at aiven point and a starting point.

The curvature of the persistent chain is given by:

$$
\langle\cos \psi\rangle=\exp \left(-s / l_{p}\right)
$$

where $s$ is a contour length of a chain (i.e. the length from the beginning of a chain to a given point), $l_{p}$ is a persistent length. As follows from the eq. (2), the curvature changes $e$ times along a chain of a length $l_{p}$. If $\Lambda$ is a total contour length and $\vec{u}(s)$ represents a unit vector characterizing the direction of the chain at aiven point, which is at a distance $s$ from the beginning of the chain, the vector $\vec{R}$ connecting the starting and ending points of a chain can be described as:

$$
\vec{R}=\int_{0}^{\Lambda} \vec{u}(s) d s
$$


The root mean square value of this parameter is given by:

$$
\left\langle\vec{R}^{2}\right\rangle=\int_{0}^{\Lambda} \vec{u}\left(s_{1}\right) d s_{1} \int_{0}^{\Lambda} \vec{u}\left(s_{2}\right) d s_{2}
$$

The scalar product of unit vectors equals to:

Finally, one obtains:

$$
\vec{u}\left(s_{1}\right) \vec{u}\left(s_{2}\right)=\cos \left(d \vec{s}_{1}, d \vec{s}_{2}\right)=\exp \left(\frac{-\left(s_{1}-s_{2}\right)}{l_{p}}\right) ; \quad s_{1}>s_{2}
$$

$$
\begin{array}{r}
\left\langle\vec{R}^{2}\right\rangle=\int_{0}^{\Lambda} \int_{0}^{\Lambda} \exp \left(-\frac{\left(s_{1}-s_{2}\right)}{l_{p}}\right) d s_{1} d s_{2}=2 \int_{0}^{\Lambda} \int_{0}^{s_{1}} \exp \left(-\frac{\left(s_{1}-s_{2}\right)}{l_{p}}\right) d s_{2} d s_{1} \\
\int_{0}^{s_{1}} \exp \left(-\frac{s_{1}}{l_{p}}\right) \exp \left(\frac{s_{2}}{l_{p}}\right) d s_{2}=\left.\exp \left(-\frac{s_{1}}{l_{p}}\right) l_{p} \exp \left(\frac{s_{2}}{l_{p}}\right)\right|_{0} ^{s_{1}}=l_{p}\left(1-\exp \left(-\frac{s_{1}}{l_{p}}\right)\right) \\
\left\langle\vec{R}^{2}\right\rangle=2 l_{p} \int_{0}^{\Lambda}\left(1-\exp \left(-\frac{s_{1}}{l_{p}}\right)\right) d s_{1}=2 l_{p} \Lambda+\left.2 l_{p}^{2} \exp \left(-\frac{s_{1}}{l_{p}}\right)\right|_{0} ^{\Lambda}=2 l_{p}^{2}\left\{\frac{\Lambda}{l_{p}}-1+\exp \left(-\frac{\Lambda}{l_{p}}\right)\right\}
\end{array}
$$
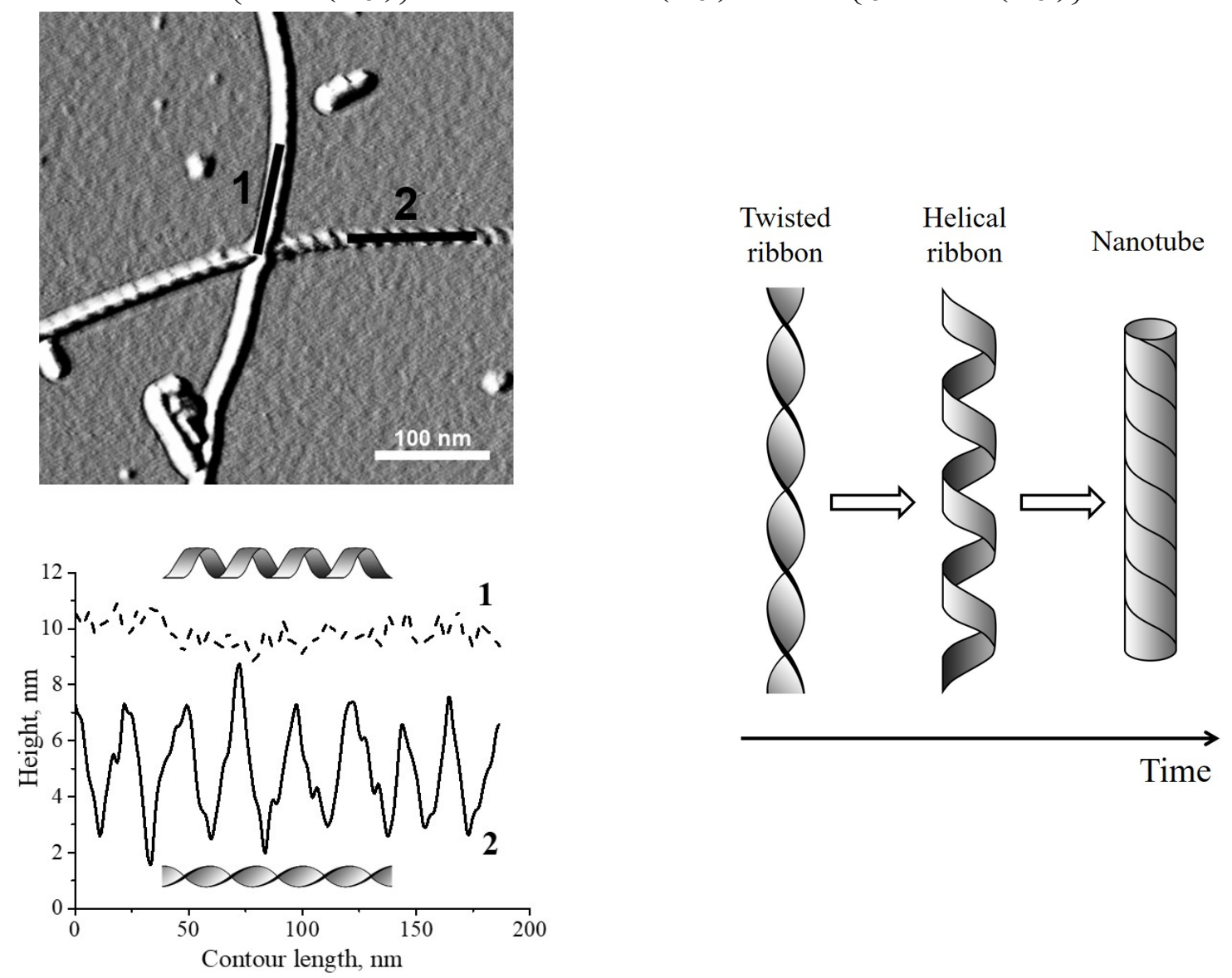

Fig. 1. Height profiles of G26R/W@8 amyloid fibrils along the contour length (left panel). Schematic representation of different polymorphs of amyloid fibrils (right panel).

It should be noted that the expression for the root mean square distance between the ends of a persistent chain may be used for the estimation of the root mean square distance between any points of a chain, $s_{1}$ and $s_{2}$ :

$$
\left\langle\vec{R}^{2}\right\rangle=f\left(s_{1}-s_{2}\right)=2 l_{p}^{2}\left\{\frac{\left|s_{1}-s_{2}\right|}{l_{p}}-1+\exp \left(-\frac{\left|s_{1}-s_{2}\right|}{l_{p}}\right)\right\}
$$

From the other hand, the persistent length relates to the two important elastic characteristics of amyloid fibrils:

$$
l_{p}=E I / k_{B} T
$$


where $E$ is the modulus of elasticity (the Young's modulus), $I$ is the second moment of inertia. While the Young's modulus is determined mainly by the amino acid sequence of monomeric polypeptide chain, the second moment of inertia is a geometric factor which depends on the shape and size of fibril cross section [15]. Given that the cross section of the amyloid fibril in a twisted ribbon configuration is a rectangle, while that in the configuration of helical ribbon is a circle, the second moments of inertia for TR $\left(I_{T R}\right)$ and HR $\left(I_{H R}\right)$ may be written as:

$$
I_{T R}=\frac{w h^{3}}{12}, \quad I_{H R}=\frac{\pi h^{4}}{64}
$$

In turn, the Young's modulus and the second moment of inertia are interrelated by the following equation:

$$
E=B / I
$$

where $B$ is the bending rigidity coefficient.

For the quantitative estimation of the mechanical properties (persistent length, Young's modulus, second moment of inertia) of the G26R/W@8 amyloid fibrils within the framework of the worm-like model, the AFM image presented in Fig. 1 was analyzed using the Easyworm software [16]. The calculations were made separately for TR and HR conformations.
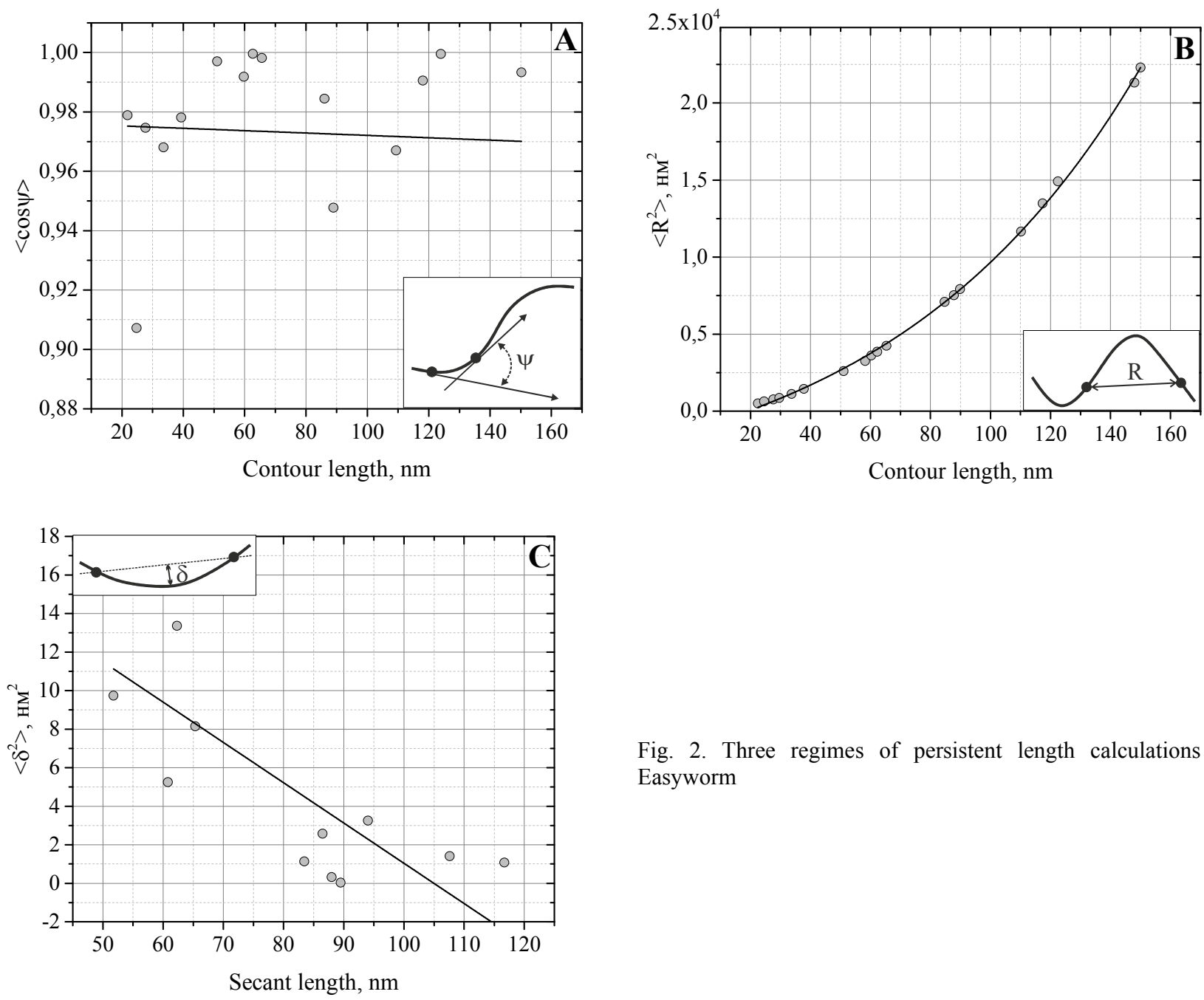

Fig. 2. Three regimes of persistent length calculations in Easyworm

The Easyworm represents the graphical interface of the algorithm of AFM data treatment, whose mathematical basis was created in MATLAB. The three regimes of persistent length calculations are available in Easyworm (Fig. 2):

Regime 1 - the measurement of the angle between the tangents at two points of the fibril segments. Persistent length is determined by eq. (2).

Regime 2 - the calculation of the mean square end-to-end distance of the fibril. Persistent length is determined by eq. (8).

Regime 3 - the determination of mean square of the deviations $\delta$ to secant midpoints at two points of the fibril segments. Persistent length is determined as:

$$
\left\langle\delta^{2}\right\rangle=\frac{L^{3}}{24 l_{p}}
$$


Table

Mechanical properties of two polymorphic forms of G26R/W@8 amyloid fibrils

\begin{tabular}{|c|c|c|}
\hline Parameter & TR & HR \\
\hline Persistent length, $\mu \mathrm{m}$ & $2.23 \pm 0.24$ & $4.17 \pm 0.61$ \\
\hline Bending rigidity, $\mathrm{N} \cdot \mathrm{m}^{2}$ & $(9.17 \pm 1.07) \times 10^{-27}$ & $(17.15 \pm 2.11) \times 10^{-27}$ \\
\hline Second moment of inertia, $\mathrm{m}^{4}$ & $(2.91 \pm 0.93) \times 10^{-35}$ & $(4.91 \pm 0.93) \times 10^{-34}$ \\
\hline Young's modulus, $\mathrm{GPa}$ & $3.15 \pm 0.72$ & $3.54 \pm 0.77$ \\
\hline
\end{tabular}

Fig. 2 represents the approximation of the AFM data acquired for G26R/W@8 amyloid fibrils in TR configuration, by the eqs. (2), (8), (13). As seen from this figure, the best fit between the theory and experiment is achieved in the Regime 2 (Fig. 2, B). An analogous result was obtained also for HR configuration. Therefore, the values of persistent length, derived from eq. (8), were used for the estimation of $E, I$ and $B$. The mechanical characteristics of fibrillar G26R/W@8 calculated in such a way are summarized in Table 1. The results obtained show that the amyloid fibrils represent rigid, mechanically stable structures. For the sake of comparison, the elastic modulus of rubber is $0.005 \mathrm{GPa}$, of glass and aluminum is $70 \mathrm{GPa}$, of bones is $30 \mathrm{GPa}$, and that of steel is $200 \mathrm{GPa}$ [17]. Another mechanical peculiarity of the examined amyloid fibrils is the fact that the aggregates in a HR conformation have the persistent length twice higher than that in a TR conformation. This finding reflects the expected increase of fibril rigidity upon topological evolution from a twisted to a helical ribbon during fibril maturation and thickening. Using the theoretical approaches of polymer statistics, Adamcik and co-workers have analyzed the nanomechanical properties of amyloid fibrils based on the AFM images [18]. The authors postulated that any fibrillar aggregate may be described as a multistranded fibril composed of $1-5$ filaments. The helicity of the resulted fibril depends on the interactions between the filaments, while the persistent length is determined by the number of protofilaments. More specifically, the rise in persistent length with the number of filaments is supposed to be due to the increase in cross-sectional moment of inertia.

The exceptional mechanical characteristics of amyloid fibrils are explained by their unique highly ordered structure, the main element of which is represented by the $\beta$-strands. A high density of the inter-backbone H-bonds which stabilize the integrity of the fibril plays a decisive role in determining the rigidity of fibrillar aggregates. Furthermore, the remarkable elastic properties of amyloid fibrils were reported to be a crucial factor underlying their cytotoxic potential. In particular, it was supposed that the mechanical disruption of cell membranes by amyloids arises from the fact that the Young's modulus of protein aggregates $(1-10 \mathrm{GPa})$ substantially exceeds that of cellular membranes $(\sim 100 \mathrm{kPa})$. Thus, the findings presented here may help in creating the basis for understanding the mechanics-driven cytotoxic activities of amyloid fibrils.

\section{CONCLUSIONS}

In summary, the atomic force microscopy was utilized to perform the mechanical characterization of the apolipoprotein A-I amyloid fibrils. The set of elastic parameters, including the Young's modulus, persistent length, bending rigidity and the second moment of inertia was calculated for the two polymorphic forms of fibrillar aggregates - twisted ribbon and helical ribbon. A helical ribbon configuration was found to possess a higher mechanical strength and stiffness as compared to a twisted ribbon state. Given that the amyloid elastic characteristics correlate with its pathogenic potential, the results obtained highlight the key role of fibril maturation in determining its cytotoxicity.

\section{ORCID IDs}

DValeriya Trusova, https://orcid.org/0000-0002-7087-071X; DKateryna Vus, http://orcid.org/0000-0003-4738-4016

DIga Zhytniakivska, https://orcid.org/0000-0001-9554-0090; DUliana Tarabara, https://orcid.org/0000-0002-7677-0779

(D)Hiroyuki Saito, https://orcid.org/0000-0003-1497-1425; (DGalyna Gorbenko, http://orcid.org/0000-0002-0954-5053

\section{REFERENCES}

[1] J. Vaquer-Alicea, and M. Diamond, Annu. Rev. Biochem. 88, 785-810 (2019), https://doi.org/10.1146/annurev-biochem061516-045049.

[2] S. Khatun, A, Singh, D. Mandal, A. Chandra, and A. Gupta, Phys. Chem. Chem. Phys. 21, 20083-20094 (2019), https://doi.org/10.1039/C9CP03238J.

[3] A. Buell, Biochem. J. 476, 2677-2703 (2019), https://doi.org/10.1042/BCJ20160868.

[4] O. Galzitskaya, Curr. Protein Pept. Sci. 20, 630-640 (2019), https://doi.org/10.2174/1389203720666190125160937.

[5] P. Arosio, T. Knowles, and S. Linse, Phys. Chem. Chem. Phys. 17, 7606-7618 (2015), https://doi.org/10.1039/c4cp05563b.

[6] M. Jucker, and L. Walker, Nature 501, 45-51 (2013), https://doi.org/10.1038/nature12481.

[7] S. Zhang, M. Andreasen, J. Nielsen, L. Liu, E. Nielsen, J. Song, G. Li et al., Proc. Natl. Acd. Sci. USA 110, $2798-2803$ (2013), https://doi.org/10.1073/pnas.1209955110.

[8] V. Trusova, Biophys. Rev. Lett. 10, 135-156 (2015), https://doi.org/10.1142/S1793048015300029.

[9] J. Liu, M. Tian, and L. Shen, Chem. Commun. 56, 3147-3150 (2020), https://doi.org/10.1039/C9CC10079B.

[10] R. Tycko, Neuron 86, 632-645 (2015), https://doi.org/10.1016/j.neuron.2015.03.017.

[11] M. Kollmer, W. Close, L. Funk, J. Rasmussen, A. Bsoul, A. Schierhorn, M. Schmiddt et al., Nat. Commun. 10, 4760-4767 (2019), https://doi.org/10.1038/s41467-019-12683-8.

[12] E. Adachi, H. Nakajima, C. Mizuguchi, P. Dhanasekaran, H. Kawashima, K. Nagao, K. Akaji et al., J. Biol. Chem. 288, 28482856 (2013), https://doi.org/10.1074/jbc.M112.428052.

[13] M. Girych, G. Gorbenko, V. Trusova, E. Adachi, C. Mizuguchi, K. Nagao, H. Kawashima et al., J. Struct. Biol. 185, 116-124 (2014), https://doi.org/10.1016/j.jsb.2013.10.017. 
[14] C. Bouchiat, M. Wang, J.-F. Allemand, T. Strick, S. Block, and V. Croquette, Biophys. J. 76, 409-413 (1999), https://doi.org/10.1016/S0006-3495(99)77207-3.

[15] I. Usov, and R. Mezzenga, ACS Nano 8, 11035-11041 (2014), https://doi.org/10.1021/nn503530a.

[16] G. Lamour, J. Kirkegaard, H. Li, T. Knowles, and J. Gsponer, Source Code Biol. Med. 9, 16-21 (2014), https://doi.org/10.1186/1751-0473-9-16.

[17] B. Choi, G. Yoon, S. Lee, and K. Eom, Phys. Chem. Chem. Phys. 17, 1379-1389 (2015), https://doi.org/10.1039/c4cp03804e.

[18] J. Adamcik, J.-M. Jung, J. Flakowski, P. Rios, G. Dietler, and R. Mezzenga, Nat. Nanotech. 5, 423-428 (2010), https://doi.org/10.1038/NNANO.2010.59.

НАНОМЕХАНІЧНІ ХАРАКТЕРИСТИКИ АМІЛОЇДНИХ ФІБРИЛ АПОЛІПОПРОТЕЇНУ А-І Валерія Трусова ${ }^{a}$, Катерина Вуса ${ }^{\mathrm{a}}$, Ольга Житняківська ${ }^{\mathrm{a}}$, Уляна Тарабара $^{\mathrm{a}}$, Хіроюкі Сайто ${ }^{\mathrm{b}}$, Галина Горбенко

${ }^{a}$ Кафедра медичної фізики та біомедччних нанотехнологій, Харківський національний університет імені В.Н. Каразіна м. Свободи 4, Харків, 61022, Украӥна

${ }^{b}$ Кафедра біофізичної хімії, Фармацевтичний університет

Місасагі-Накаучі-чо 5, Ямашина-ку, м. Кіото, 607-8414, Японія

Амілоїдні фібрили - це особливий тип білкових агрегатів, який привертає невпинно зростаючу увагу завдяки їх важливій ролі в молекулярній етіології широкого кола захворювань. Амілоїдні фібрили представляють собою високовпорядковані самоасоціати, що характеризуються крос- $\beta$-складчатою структурою. Така організація фібрил відповідальна за їх нерозчинність та особливі механічні властивості. Висока жорсткість фібрилярних білкових агрегатів забезпечується великою кількістю водневих зв'язків, які стабілізують $\beta$-складчастий каркас амілоїдних фібрил. Все більшого обгрунтування набуває припущення, що фізичні властивості амілоїдів, особливо їх механічні характеристики, відіграють ключову роль у визначенні їх цитотоксичної дії. У зв'язку із цим, встановлення кореляції між еластичними властивостями амілоїдних агрегатів та їх цитотоксичністю $є$ вельми необхідним. У даній роботі 3 використанням атомної силової мікроскопії (ACM) були проаналізовані амілоїдні фібрили мутанту G26R/W@8 N-термінального фрагменту аполіпопротеїну A-I (апоА-I). Аналіз АСМ мікрофотографій виявив наявність двох поліморфних форм фібрил апоА-I - закрученої стрічки та спіральної стрічки. Кількісна характеризація еластичних властивостей апоА-І була проведена у рамках моделі персистентного ланцюга Порода-Краткі, з використанням програмного пакету Easyworm. Цей пакет дозволяє аналізувати зображення окремого поліпептидного ланцюга, отримані за допомогою АСМ, та визначати персистентну довжину ланцюга у трьох режимах в залежності від співвідношення контурної та персистентної довжини. Набір параметрів, отриманих внаслідок такого аналізу, включав модуль Юнга, персистентну довжину, жорсткість при вигині та другий момент інерції. Виявилось, що розраховані параметри мали більші значення для конфігурації спіральної стрічки у порівнянні із конфігурацією закрученої стрічки. Це свідчить про те, що спіральна стрічка $є$ більш жорсткою та механічно стабільною конфігурацією. Отримані результати є важливими для більш глибокого розуміння механічно-контрольованої патологічної дії амілоїдних фібрил.

КЛЮЧОВІ СЛОВА: амілоїдні фібрили, механічні властивості, персистентний ланцюг, атомно-силова мікроскопія, Easyworm

НАНОМЕХАНИЧЕСКИЕ ХАРАКТЕРИСТИКИ АМИЛОИДНЫХ ФИБРИЛЛ АПОЛИПОПРОТЕИНА А-І

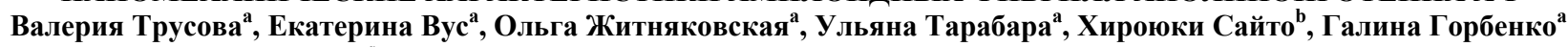

${ }^{a}$ Кафедра медицинской физики и биомедицинских нанотехнологий

Харьковский национальный университет имени В.Н. Каразина

пл. Свободы 4, Харьков, 61022, Украина

${ }^{b}$ Кафедра биофизической химии, Фармацевтический университет,

Мисасаги-Накаучи-чо 5, Ямашина-ку, Киото, 607-8414, Япония

Амилоидные фибриллы - это особый тип белковых агрегатов, которые привлекают все большее внимание благодаря их важной роли в молекулярной этиологии широкого круга заболеваний. Амилоидные фибриллы представляют собой высокоупорядоченные самоассоциаты, которые характеризуются кросс- $\beta$-складчатой структурой. Такая организация фибрилл ответственна за их нерастворимость и особые механические свойства. Высокая жесткость фибриллярных агрегатов белков обеспечивается большим количеством водородных связей, которые стабилизируют $\beta$-складчатый каркас амилоидных фибрилл. Все большее обоснование получает предположение о том, что физические свойства амилоидов, особенно их механические характеристики, играют ключевую роль в определении их цитотоксического действия. В связи с этим, установление корреляции между эластическими свойствами амилоидных агрегатов и их цитотоксичностью является актуальной задачей. В данной работе с использованием атомно-силовой микроскопии (АСМ) были проанализированы амилоидные фибриллы мутанта G26R/W@8 N-терминального фрагмента аполипопротеина A-I. Анализ АСМ изображений выявил наличие двух полиморфных форм фибрилл апоА-I - закрученной ленты и спиральной ленты. Количественная характеристика эластических свойств апоА-І была проведена в рамках модели персистентной цепи Порода-Кратки, с использованием программного пакета Easyworm. Данный пакет позволяет анализировать фотографии отдельной полипептидной цепи, полученные с помощью АСМ, и определять персистентную длину цепи в трех режимах в зависимости от соотношения между контурной и персистентной длиной. Набор параметров, полученных в результате такого анализа, включал модуль Юнга, персистентную длину, жесткость при изгибе и второй момент инерции. Оказалось, что рассчитанные параметры были выше для конфигурации спиральной ленты, чем для конфигурации закрученной ленты. Это свидетельствует в пользу того, что спиральная лента представляет собой более жесткую и механически стабильную конфигурацию. Полученные результаты являются важными для более глубокого понимания механически-контролируемого патологического действия амилоидных фибрилл.

КЛЮЧЕВЫЕ СЛОВА: амилоидные фибриллы, механические свойства, персистентная цепь, атомно-силовая микроскопия, Easyworm 